Check for updates

Cite this: Mater. Adv., 2021, 2,6344

Received 12th May 2021 Accepted 25th August 2021

DOI: 10.1039/d1ma00432h

rsc.li/materials-advances

\title{
High-performance wide bandgap perovskite solar cells fabricated in ambient high-humidity conditions $\dagger$
}

\author{
Ugur Deneb Menda, (D) * Guilherme Ribeiro, Daniela Nunes, Tomás Calmeiro, (1D) \\ Hugo Águas, (D) Elvira Fortunato, (D) Rodrigo Martins and Manuel J. Mendes (D)*
}

\begin{abstract}
Lead-halide perovskite solar cells (PSCs) are currently the most promising emergent thin-film photovoltaic technology, having already reached power conversion efficiency (PCE) levels of state-ofthe-art wafer-based silicon cells. The class of wide bandgap PSCs has also demonstrated high PCE values, thus becoming highly attractive for top sub-cells in tandem devices constructed with silicon or other types of bottom sub-cells. In this study, wide bandgap double-halide $\left(\mathrm{Cs}_{0.17} \mathrm{FA}_{0.83} \mathrm{Pbl}_{3-x} \mathrm{Br}_{x}\right)$ perovskite absorbers were developed with different bromine content, aiming to obtain bandgap values between 1.66 to $1.74 \mathrm{eV}$, by a glovebox-free (ambient) procedure. Low-cost inorganic materials, i.e. $\mathrm{TiO}_{2}$ and CuSCN, were used for the electron and hole transport layers, respectively. The 1.70 eV bandgap perovskite resulted in the highest reproducibility and stability (>80\% initial PCE after 3500 hours) properties of the PSCs, remarkably attaining 16.4\% PCE even with ambient and high humidity ( 70\%) fabrication conditions.
\end{abstract}

\section{Introduction}

Inorganic-organic metal-halide perovskite solar cells (PSCs) have become the most attractive class of thin-film photovoltaic (PV) technology in the last decade, due to the astonishingly fast rise of their power conversion efficiency (PCE) values from 3.8 to $25.5 \%$ within 10 years only. ${ }^{1,2}$ Besides, this emergent $\mathrm{PV}$ technology has shown enormous potential for cost savings, due to the non-vacuum low-temperature deposition and crystallization $^{3}$ of the cell layers, enabling also application on inexpensive flexible substrates. ${ }^{4-8}$

The inorganic-organic hybrid perovskites have the general formula $\mathrm{ABX}_{3}$, where $\mathrm{A}$ is a monovalent cation composed of methylammonium (MA: $\mathrm{CH}_{3} \mathrm{NH}_{3}{ }^{+}$), formamidinium (FA: $\mathrm{CH}_{3}\left(\mathrm{NH}_{2}\right)_{2}{ }^{+}$), and/or cesium $\left.\left(\mathrm{Cs}^{+}\right)\right),{ }^{9} \mathrm{~B}$ is a divalent metal cation (e.g. $\left.\mathrm{Pb}^{2+}, \mathrm{Ge}^{2+}, \mathrm{Sn}^{2+}\right)$ and $\mathrm{X}$ is a halide anion $\left(\mathrm{I}^{-}, \mathrm{Br}^{-}\right.$, and $\left./ \mathrm{or} \mathrm{Cl}^{-}\right) .^{10}$ The highest PCEs for single-junction devices have been attained with perovskite absorbers with $\sim 1.55 \mathrm{eV}$ bandgap. Nonetheless, their easy bandgap tuning favours PSC application in tandem (double-juction) architectures, not only with wide-bandgap PSC/ low-bandgap PSC configurations ${ }^{11,12}$ but also with wide-bandgap

i3N/CENIMAT, Department of Materials Science, Faculty of Science and Technology, Universidade NOVA de Lisboa and CEMOP/UNINOVA, Campus de Caparica, 2829516 Caparica, Portugal. E-mail: u.menda@fct.unl.pt, mj.mendes@fct.unl.pt $\dagger$ Electronic supplementary information (ESI) available. See DOI: 10.1039/ d1ma00432h
PSCs $^{13,14}$ coupled to distinct types of bottom cells based on silicon ${ }^{15-17}$ or CIGS materials. ${ }^{18,19}$ In this work we fabricated wide-bandgap perovskite layers with different bandgap values by changing the bromine (Br) to iodine (I) ratio at the halide anion site, while a mixture of FA and Cs was used for the A cations.

Albeit PSCs are already competitive with other PV technologies in terms of PCE values, the commercialisation of perovskite-based PV modules is still in suspense; not only because of the well-known stability issues but also due to the presently high fabrication costs. However, techno-economic assessments indicate that PSCs hold the promise of becoming one of the most affordable PV technologies with low levelized cost of energy (LCOE) in the near future. ${ }^{20,21}$ Yet, state-of-the-art solutionprocessed PSCs are commonly fabricated in temperature and humidity controlled glovebox systems, mainly due to the highly environmentally-sensitive organic materials composing the structure. ${ }^{22,23}$ This adds critical processing costs and strong limitations in the scalability of this PV technology, thus hindering its industrial exploitation. Therefore, there is a strong motivation to develop the production of high-efficient and stable PSCs in ambient atmosphere conditions, as achieved in this work.

Previous studies in the literature ${ }^{24-28}$ explored this possibility, but mainly employing MA-based perovskites with conventional $(\sim 1.55 \mathrm{eV})$ bandgap for single-junction cells. These and many other works have analysed the influence of the ambient humidity on the deposition and annealing of the perovskite layers. Even though it has been generally believed that humidity 
is an adverse detrimental factor in the PSCs' processing, some contributions have challenged this view. For instance, Pathak et al. reported that the humidity can improve the perovskite crystallinity, and thus enhance the PSCs' efficiency. ${ }^{29}$ Trughton et al. fabricated PSCs in high relative humidity (RH) conditions, up to $75 \%$, by applying solvent engineering using ethyl acetate as an antisolvent to absorb moisture during the perovskite layer deposition. ${ }^{30}$ In 2019, Wang et al. published a detailed study concerning the humidity impacts on $\mathrm{MAPbI}_{3}$ PSCs, presenting methods for deposition of the perovskite layers in high-mid and low humidity conditions. ${ }^{31}$ The authors claimed that, by preheating the substrates before the perovskite layer deposition, the humidity effect on the layer quality and properties can be minimized, thus naming this a humidity-insensitive antisolvent method. Preheating the substrate before the perovskite layer deposition in high humidity levels has also been investigated by Sveinbjörnsson et al. for $\left(\mathrm{FAPbI}_{3}\right)_{1-x}\left(\mathrm{MAPbBr}_{3}\right)_{x}$ perovskite films, showing that preheating has a strong influence on the thickness and the uniformity of the perovskite layer. ${ }^{32}$ Cheng et al. fabricated $\mathrm{MAPbI}_{3}$ PSCs with inverted layer structure via a twostep deposition method, observing that moisture and oxygen can be removed by preheating the substrate after the first step of $\mathrm{PbI}_{2}$ deposition. $^{33}$

Nevertheless, despite all the great developments thus far, at present there is still no agreement in the literature regarding the favorable PSC processing conditions in air/humid conditions. Besides, up to the authors' knowledge, the present study is the first report demonstrating highly efficient wide-bandgap PSCs deposited in ambient air conditions with high humidity.

Another critical limitation to the commercialization of PSCs concerns the material costs of the present highly efficient devices. In PSCs, the perovskite absorber is sandwiched between selective contacts for the photo-generated carriers extraction: the electron (ETL) ${ }^{34}$ and hole (HTL) ${ }^{35}$ transport layers, which block the opposite charges to avoid recombination and current loss. $\mathrm{TiO}_{2}$ has been the most commonly used ETL material, benefiting from a favorable band alignment with the perovskite, either in compact form for planar cells, ${ }^{36}$ in mesoporous films with pristine $\mathrm{TiO}_{2}$ crystalline layers ${ }^{37}$ as employed in this work, or even with further ETL improvements. ${ }^{38-40}$ Being an inexpensive abundant material, $\mathrm{TiO}_{2}$ does not significantly affect the PSCs' material costs, but the same cannot be said for the conventional HTL materials. Namely, the common organic compounds (Spiro-MeOTAD, PTAA or P3HT) used to synthesize the HTLs are quite expensive. One of the most costly is the typically employed Spiro-MeOTAD, whose price is currently above $300 €$ per $g$ mainly due to the high number of synthesis and purification steps, as well as reaction steps down to $-78{ }^{\circ} \mathrm{C}$ required for its production. ${ }^{37,41-43}$ This also strongly boosts the CAPEX (capital expenditure) and LCOE of PSC technology.

As such, in view of enabling the market deployment of perovskite-based PV, it is extremely desirable to replace such expensive organic-based HTL materials by inexpensive compounds. There is a recent strong interest towards alternative inorganicbased HTLs, such as CuSCN (copper(I) thiocyanate) or $\mathrm{NiO}_{x}$, not only due to their much lower material cost (e.g. CuSCN costs $\sim 300$ times less than Spiro-MeOTAD), ${ }^{35,44}$ but also because they are much more chemically and thermally robust, thus enabling improved PSC stability under environmental conditions. CuSCN revealed to be one the most efficient and less expensive material for the conventional $\mathrm{n}-\mathrm{i}-\mathrm{p}$ PSC structure, while $\mathrm{NiO}_{x}$ has been mainly used in inverted (p-i-n) PSCs. ${ }^{45-47}$

Here, we present wide-bandgap (WBG) PSCs using low cost, inorganic CuSCN, as the hole transport material, and each step of the synthesis, depositions (except back contact evaporation) and analysis are performed in ambient enviroment with high humidity conditions $(>70 \%)$. Our best performing cell exhibits $16.4 \%$ PCE with $V_{\text {oc }}=1.08 \mathrm{~V}, J_{\text {sc }}=21.0 \mathrm{~mA} \mathrm{~cm}^{-2}, \mathrm{FF}=0.72$. The PSCs also exhibit long term stability, maintaining $>80 \%$ of the initial PCE for 3500 hours without any encapsulation. Fig. 1 shows the schematic of the solar cells' layers and energy band diagram of the devices' structure. (a)

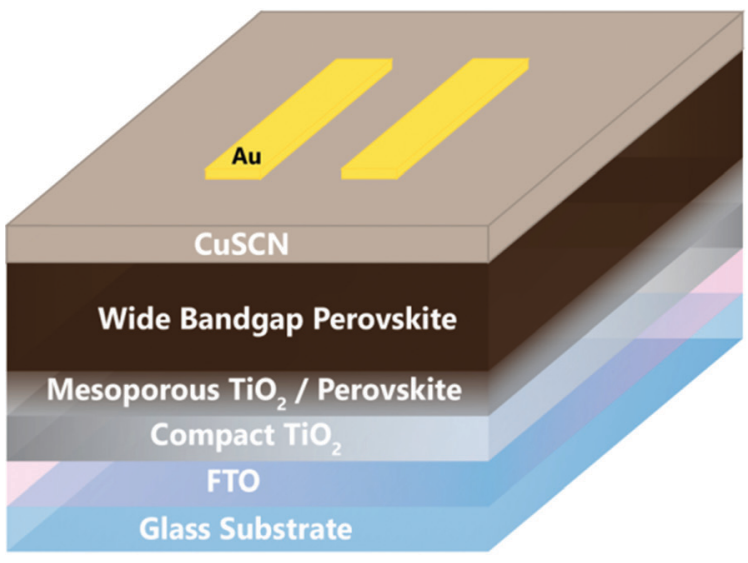

(b)

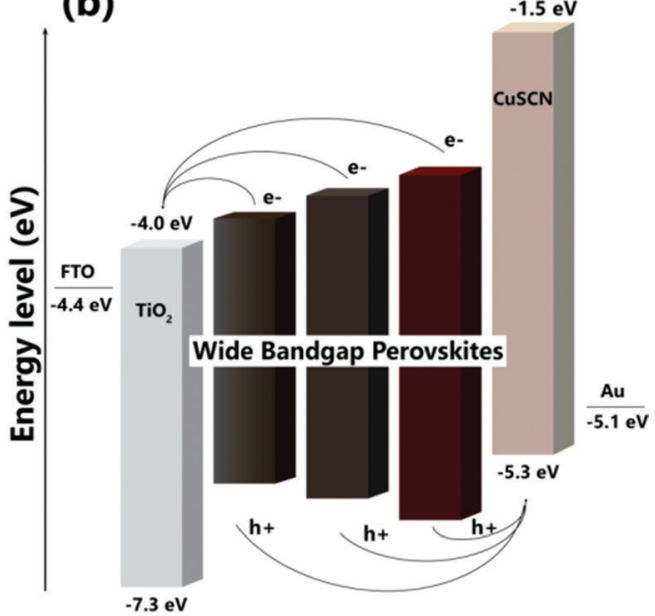

Fig. 1 Architecture (a) and energy band diagram (b) of the wide-bandgap (WBG) perovskite solar cells (PSCs) fabricated in this work, with a superstrate $(n-i-p)$ layer structure, under ambient environment with high humidity conditions ( $>70 \%$ ). 


\section{Results and discussion}

\subsection{Analysis of wide-bandgap (WBG) perovskite layers}

WBG perovskite films of the type $\mathrm{Cs}_{0.17} \mathrm{FA}_{0.83} \mathrm{PbI}_{3-x} \mathrm{Br}_{x}$ were first deposited on FTO-coated glass substrates for optical, structural and morphological characterization. The thicknesses of the layers measured by profilometry are approximately $550 \pm$ $50 \mathrm{~nm}$. It was observed that the change in $\mathrm{Br}$ content influences the layers' morphology, causing surfaces wrinkles with roughness up to $45 \mathrm{~nm}$ as presented further below, but it does not have a considerable impact on the average thickness of the perovskite layers.

Fig. 2a shows that the absorbance of the perovskite layers on the FTO substrates is more than $80 \%$ for the visible region and, depending on the bandgap value (determined by Br content, $x$ ), the absorbance onset changes in the near-infrared wavelength range. The energy bandgap $\left(E_{\mathrm{G}}\right)$ values displayed in Fig. $2 \mathrm{c}$ were determined via the steady-state photoluminescence (PL) peaks (see Fig. 2b) and the Tauc plot method (see inset of Fig. 2a) for direct bandgap semiconductors. It can be clearly seen that the $E_{\mathrm{G}}$ values increase linearly with higher $\mathrm{Br}$ content ratio, as expected. The slope of the linear regression displaying this characteristic is $\mathrm{d} E_{\mathrm{G}} / \mathrm{d} x=0.2-0.23 \mathrm{eV}$, which proves a facile tuning of the perovskite layer bandgap. The $E_{\mathrm{G}}$ values obtained from absorbance and PL concur well, with slight differences that reduce as the $\mathrm{Br}$ content increases. Besides, the observed stronger PL intensities with increasing Br content (see Fig. S1 in $\mathrm{ESI} \dagger$ ) is in agreement with the crystallinity measurements described below. ${ }^{48}$

The crystallinity of the perovskite layer is a key factor for the PSCs' efficiency. To scrutinize the crystalline properties of the perovskite absorbers depending on Br content, we calculated the Urbach energies $\left(E_{\mathrm{U}}\right)$ of the perovskite layers from the absorption spectra via eqn (1):

$$
\alpha=\alpha_{0}+\mathrm{e}^{h \nu / E_{\mathrm{U}}}
$$

where $\alpha$ is the absorption coefficient, $\alpha_{0}$ is a fitting constant and $E_{\mathrm{U}}$ is the Urbach energy. The calculated $E_{\mathrm{U}}$ values (see Table 1) are inversely proportional to the $\mathrm{Br}$ content, indicating that the crystallinity properties were enhanced with $\mathrm{Br}$ ratio $(x) .{ }^{49}$ As $x$ increases the Urbach tail energy (attributed to lattice disorder)
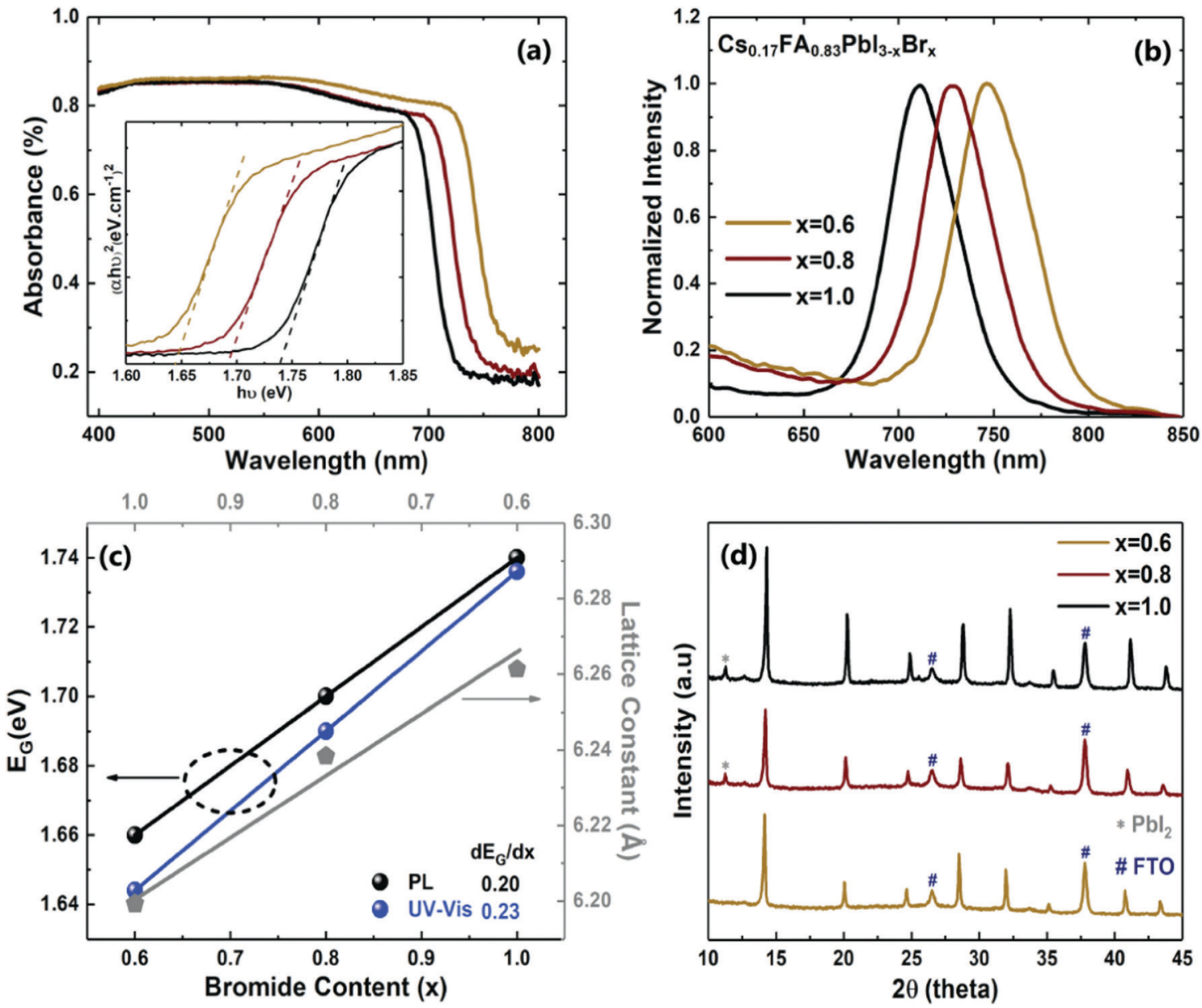

Fig. 2 Optical and structural results of $\mathrm{Cs}_{0.17} \mathrm{FA}_{0.83} \mathrm{Pbl}_{3-x} \mathrm{Br}_{x}$ perovskite layers on $\mathrm{FTO}$-coated glass substrates, with different $\mathrm{Br}$ content $(x=0.6,0.8,1.0$ ). (a) Absorbance spectra with Tauc plots $\left[(\alpha h \nu)^{2} v s\right.$. $\left.h \nu\right]$ in inset. (b) Normalized steady-state PL measurements. (c) Relation between the perovskite bandgap, $E_{\mathrm{G}}$, and the lattice constant, as a function of $\mathrm{Br}$ content. (d) X-Ray diffraction plots of the WBG perovskite layers, whose peaks are shown in further detail in Fig. S2 of the ESI. $\dagger$ 
Table 1 Urbach energy, surface roughness and average grain size values of the perovskite layers with different $\mathrm{Br}$ content in the $\mathrm{Cs}_{0.17} \mathrm{FA}_{0.83} \mathrm{P}$ $\mathrm{bl}_{3-x} \mathrm{Br}_{x}$ composition

\begin{tabular}{llll}
\hline$x(\mathrm{Br}$ content ratio) & 0.6 & 0.8 & 1.0 \\
\hline Urbach energy $\left(E_{\mathrm{U}}, \mathrm{meV}\right)$ & 63 & 57 & 53 \\
RMS roughness $(\mathrm{nm})$ & 29.68 & 42.29 & 45.02 \\
Mean grain size $(\mathrm{nm})$ & 137.3 & 190.1 & 205.6
\end{tabular}

decreases, ${ }^{49}$ thus lower values of $E_{\mathrm{U}}$ correspond to higher order in the crystal structure. The Urbach values attained for our ambient-deposited perovskite films are slightly higher than those of state-of-the-art perovskites deposited under glovebox controlled environment, ${ }^{17}$ and this leads to relatively higher open-circuit voltage deficit as analysed in ESI $\dagger$ (Fig. S4).

The aforementioned impact of $\mathrm{Br}$ content in the perovskite crystallization is confirmed by X-ray diffractometry (XRD) measurements shown in Fig. 2d. All samples display the perovskite peak around $2 \theta=14.2^{\circ}$, referring to the (100) perovskite plane. Additionally, the peaks at $20^{\circ}, 24.8^{\circ}, 28^{\circ}$ and $41.5^{\circ}$ are also found in wide-bandgap perovskite layers. ${ }^{50}$ In general, with the increase of $\mathrm{Br}$ content the XRD peak intensities increase, indicating improved crystallinity. On the other hand, the perovskite layer with the lowest $\mathrm{Br}$ content $(x=$ $0.6)$ does not exhibit any photoinactive $\mathrm{PbI}_{2}$ peaks $\left(\sim 12.6^{\circ}\right)$, which can be attributed to the lower precursor concentration, and thus better dissolubility and homogeneity of the perovskite solution. This sample also has a pronouncedly lower surface roughness determined from AFM measurements, as presented in Table 1 and discussed further below.

The XRD results show that, when increasing the $\mathrm{Br}$ : I ratio, a slight shift to higher angle values occurs, as presented in further detail in Fig. S2 of ESI. $\dagger$ It is known that higher $\mathrm{Br}$ content causes the lattice to shrink, due to the smaller size of the bromide ion when compared with the iodide ion, ${ }^{17,51}$ which transforms the tetragonal phase of $\mathrm{MAPbI}_{3}$ into the cubic phase of pure $\mathrm{MAPbBr}_{3}$. The same behaviour occurs in FA and Cs mixed-cation perovskites. ${ }^{52}$ The lattice constant calculations (see Fig. 2c) for the main perovskite peak of $2 \theta=14.2^{\circ}$ confirm such lattice contraction, and the linear relation between the lattice constant and $\mathrm{Br}$ content matches Vegard's law. ${ }^{17}$

The AFM images (shown in Fig. S3, ESI $\dagger$ ) indicate that when increasing $x$, the RMS surface roughness also increases (Table 1). The reduced roughness of the perovskites with lowest $x$ should be caused by the homogeneity of the precursor solutions and $\mathrm{Br}$ : I ratio in the layers. Also, the change in the roughness with $\mathrm{Br}$ content is attributed to the wrinkled morphology of the layers, as visualized by scanning electron microscopy (SEM, see Fig. 3). As suggested in the literature, the wrinkled-shaped structures are a consequence of compact stress during the film formation, depending on the precursor solution, antisolvent washing and annealing step. ${ }^{53-55}$

Although the wrinkled surface morphology does not significantly affect the optical properties of the films, the device performance was reduced mainly due to the less conformal deposition of the hole transport layer. ${ }^{49,56}$ As shown in ESI $\dagger$ (Fig. S3), higher $x$ leads to relatively deeper cracks in the films, which causes higher density of recombination centers, shortcircuits and overall loss in the PSCs' performance. ${ }^{57}$ Therefore, even though the perovskite layer with the highest $\mathrm{Br}$ content has better crystallinity properties and lower Urbach energy values, the resulting solar cell parameters were worse than the other cells, as shown in the next section.

Besides, as shown in the SEMs of Fig. 4 with higher magnification and in Table 1, with the increment of bromide content the average grain size of the perovskite films increases, mainly due to the appearance of large $(>300 \mathrm{~nm})$ grains causing a higher positive skewness (i.e. lower homogeneity) of the size distribution.

\subsection{PSCs' optoelectronic assessment and optimization}

2.2.1 Solar cell characterization. The current density-voltage $(\mathrm{JV})$ measurements of the solar cells composed of the WBG perovskites with the three bandgap values are shown in Fig. $5 \mathrm{a}$. The cells were fabricated with the layer structure: $\mathrm{FTO} / \mathrm{TiO}_{2} /$ $\mathrm{Cs}_{0.17} \mathrm{FA}_{0.83} \mathrm{PbI}_{3-x} \mathrm{Br}_{x} / \mathrm{CuSCN} / \mathrm{Au}$, as described in the experimental methods. All the preparations and layer depositions were
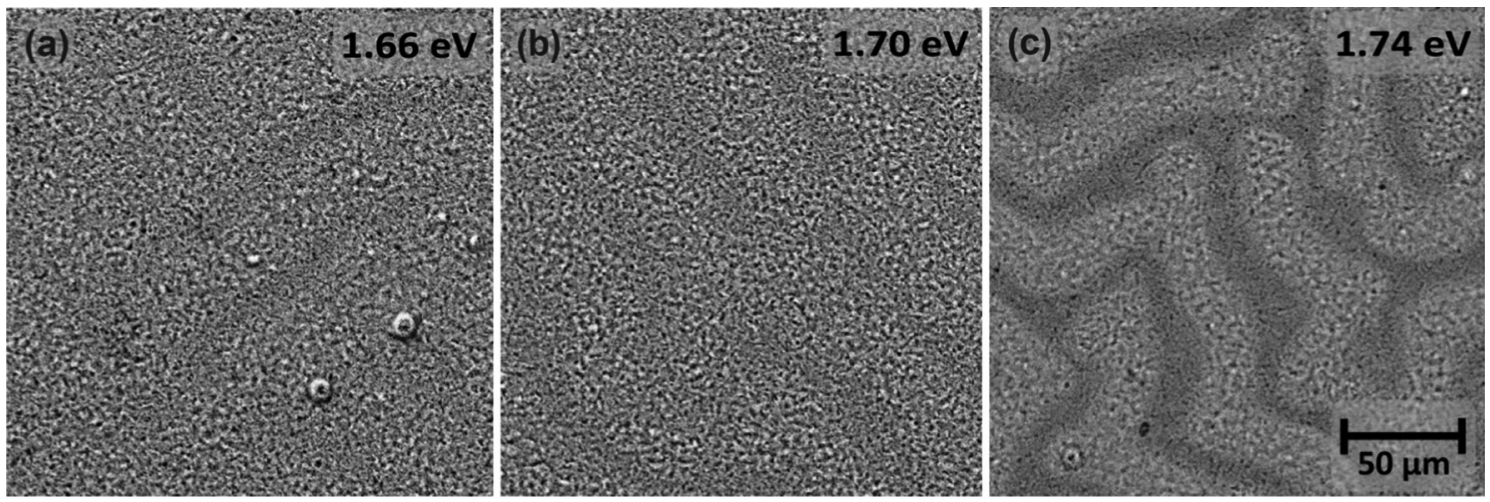

Fig. 3 Low magnification SEM images of the WBG perovskite layers on FTO-coated glass substrates, composed with different $\mathrm{Br}$ content: (a) $x=0.6$, (b) $x=0.8$, (c) $x=1.0$. It can be seen that the overall homogeneity is better for the perovskite with the lower $\mathrm{Br}$ content (and lower $E_{\mathrm{G}}$, displayed in top-right corner), while increased wrinkling is observed with higher $x$. 

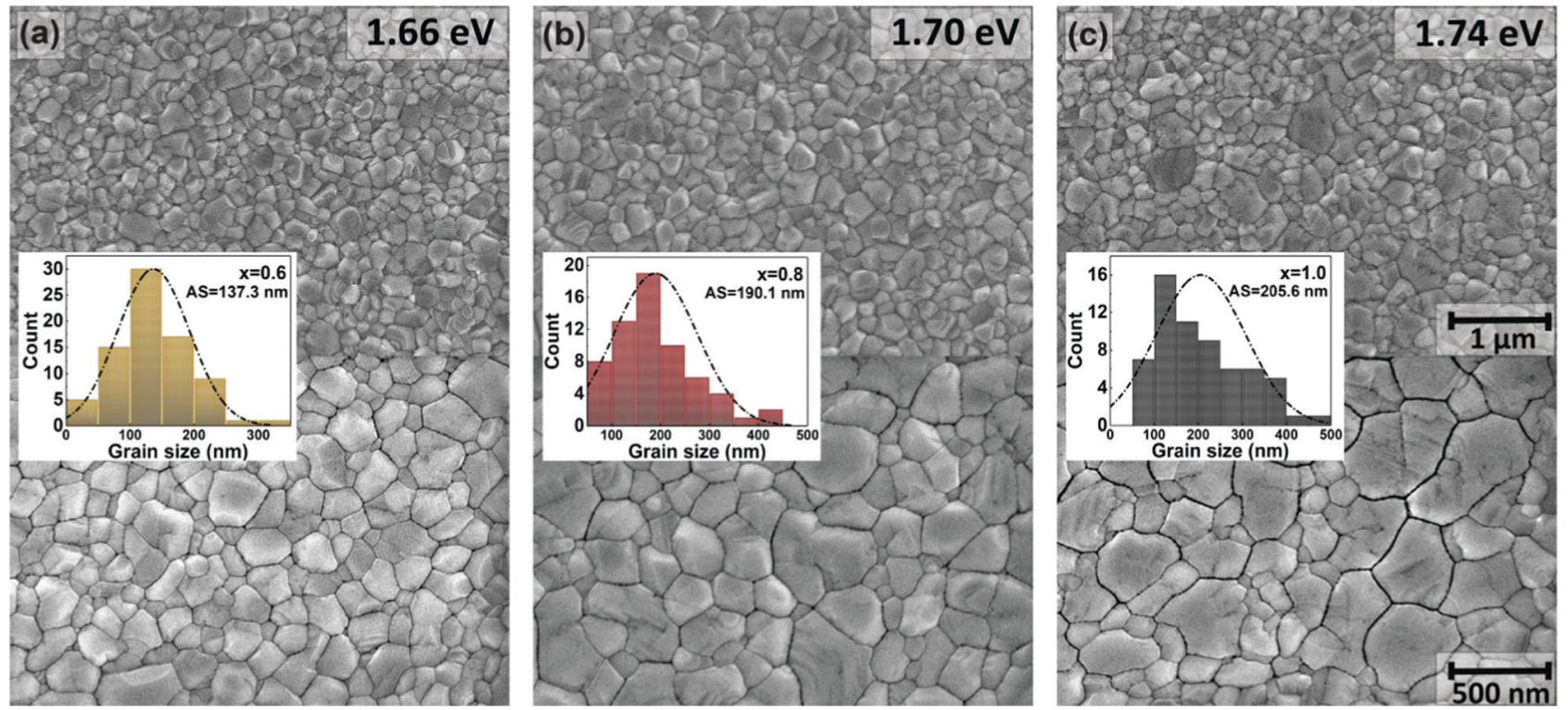

Fig. 4 Top-view SEM images of the WBG perovskite layers on FTO-coated glass substrates, composed with different Br content: (a) $x=0.6$, (b) $x=0.8$, (c) $x=1.0$. The images reveal the multi-crystalline grain structure of the films at two different magnifications. The inset histograms show the grain size distribution and average grain size (AS, also indicated in Table 1).

performed in ambient air with relative humidity, $\mathrm{RH}>70 \%$. The PV quantities of interest are shown in Fig. $5 \mathrm{~b}$ and summarized in Table 2.

As expected, there is a reduction in the PCE with increasing $E_{\mathrm{G}}$ of the perovskite absorber. However, an opposite trend should have been observed for the open-circuit voltage $\left(V_{\mathrm{oc}}\right)$, but here that is not the case since the $V_{\mathrm{oc}}$ deficit $\left(\Delta V_{\mathrm{oc}}=\frac{E_{\mathrm{G}}}{q}-V_{\mathrm{oc}}\right)$ increases with the bandgap widening (see Fig. S4, ESI $\dagger$ ). This effect is attributed to inevitable phase segregation in the perovskite layer, which becomes more pronounced when the fabrication occurs in a humid environment. ${ }^{58,59}$ Also, the aforementioned non-ideal interface properties, between the perovskite and charge transport layers, cause $V_{\text {oc }}$ reduction and higher series resistance. As for the
Table 2 Main solar cell parameters of the WBG PSCs with different $E_{G}$ values of the perovskite layer

\begin{tabular}{lllllll}
\hline$E_{\mathrm{g}}(\mathrm{eV})$ & $V_{\mathrm{oc}}(\mathrm{V})$ & $J_{\mathrm{sc}}\left(\mathrm{mA} \mathrm{cm}^{-2}\right)$ & $\mathrm{FF}$ & PCE $(\%)$ & $R_{\text {series }}(\Omega)$ & $R_{\text {shunt }}(\Omega)$ \\
\hline 1.66 & 1.00 & 20.96 & 0.71 & 15.1 & 62.8 & 25517 \\
1.70 & 1.03 & 20.43 & 0.68 & 14.4 & 86.6 & 32335 \\
1.74 & 0.99 & 17.61 & 0.64 & 11.1 & 120 & 13734 \\
\hline
\end{tabular}

shunt resistance $\left(R_{\text {shunt }}\right)$, it does not present a linear trend since it is higher for the mid-bandgap solar cell relative to the others.

Regarding the short-circuit current density $\left(J_{\mathrm{SC}}\right)$, it decreases with higher bandgap of the perovskite layer. This is expected optically since the absorbance onset is blue-shifted, as seen in Fig. $2 a^{60}$ In addition, the increased roughness with higher $\mathrm{Br}$
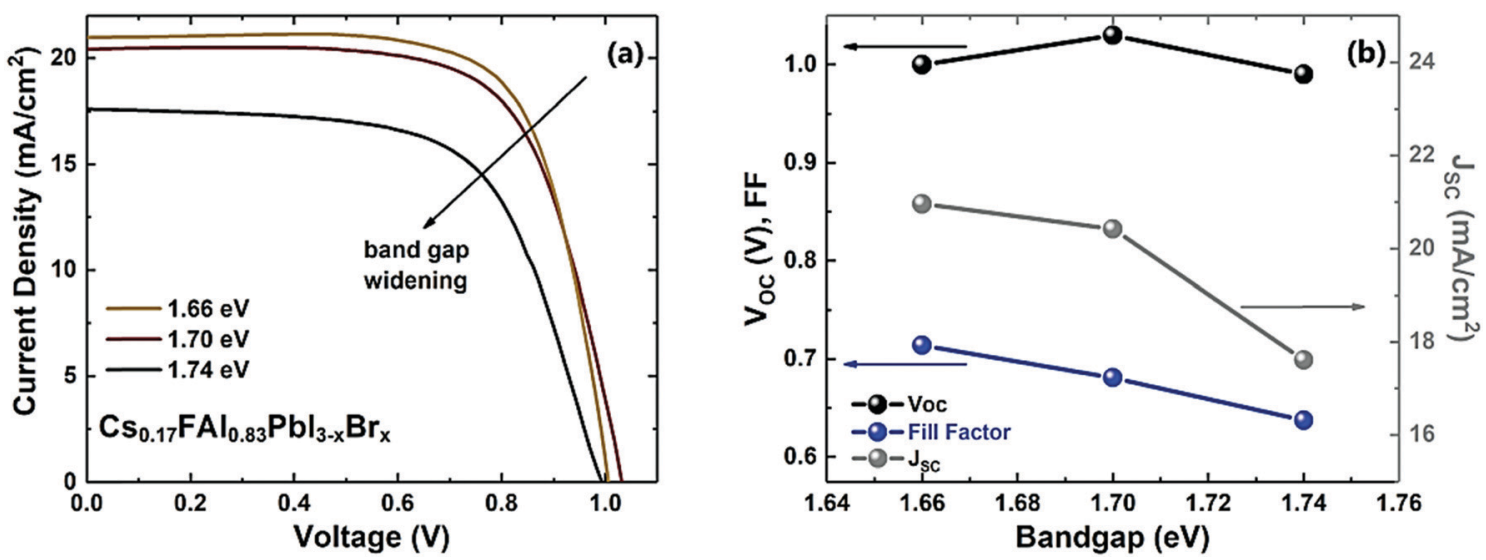

Fig. $5 \mathrm{~J}-V$ curves (a) and variation of characteristic parameters (b) of the WBG PSCs with the $E_{\mathrm{G}}$ values. 
Table 3 Solar cell parameters of the best performing WBG (1.70 eV) PSC

\begin{tabular}{llllllll}
$\begin{array}{l}\text { Best } \\
\text { results: }\end{array}$ & $E_{\mathrm{g}}(\mathrm{eV})$ & $V_{\mathrm{oc}}(\mathrm{V})$ & $J_{\mathrm{sc}}\left(\mathrm{mA} \mathrm{cm}^{-2}\right)$ & $\mathrm{FF}$ & $\mathrm{PCE}(\%)$ & $\begin{array}{l}R_{\text {series }}(\Omega) \\
R_{\text {shunt }} \\
(\Omega)\end{array}$ \\
\hline 1.70 & 1.08 & 21.0 & 0.72 & 16.4 & 73.2 & 25244
\end{tabular}

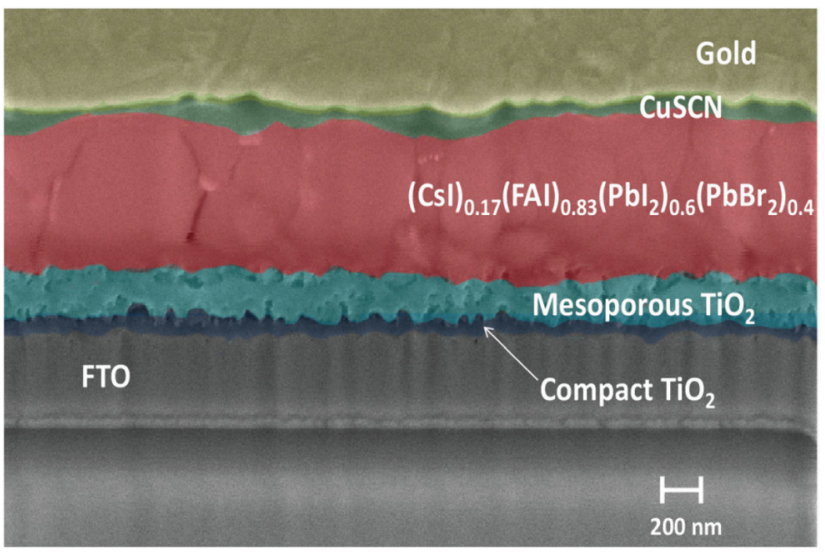

Fig. 6 Cross-sectional SEM-FIB image of $\mathrm{FTO} / \mathrm{TiO}_{2} /(\mathrm{Csl})_{0.17}(\mathrm{FAl})_{0.83}(\mathrm{P}-$ $\left.\mathrm{bl}_{2}\right)_{0.6}\left(\mathrm{PbBr}_{2}\right)_{0.4} / \mathrm{CuSCN} / \mathrm{Au}$ solar cell.

content causes more charge recombination at the interfaces, which also justifies the decrease of the fill factor $(\mathrm{FF})$ values. ${ }^{61}$
Although the highest PCE of this set was attained with the $1.66 \mathrm{eV}$ bandgap perovskite, the higher $V_{\mathrm{oc}}$ and $R_{\text {shunt }}$ with the $1.70 \mathrm{eV}$ perovskite motivated a subsequent study focused in the improvement of the $1.70 \mathrm{eV}$ PSCs, in view of their promising application for tandem solar cells due to the suitable bandgap value.

2.2.2 Optimization of WBG perovskite solar cells with $\boldsymbol{E}_{\mathrm{G}}=$ $1.7 \mathrm{eV}$ absorber. We proceed with further optimization of the wide-bandgap $(1.70 \mathrm{eV})$ PSCs with the $\mathrm{FTO} / \mathrm{TiO}_{2} /$ $\mathrm{Cs}_{0.17} \mathrm{FA}_{0.83} \mathrm{PbI}_{3-x} \mathrm{Br}_{x} / \mathrm{CuSCN} / \mathrm{Au}$ configuration, where $x=0.8$. The device fabrication procedure was fine tuned mainly in the UV treatment time applied on the ETL, substrate preheating prior to perovskite deposition, antisolvent washing and application parameters (volume, spin-coating speed) during perovskite crystallization, as well as perovskite layer annealing conditions. Consequently, we attained the highest solar cell efficiency $(\mathrm{PCE}=16.4 \%)$ of this study, presented in Table 3, employing the optimized fabrication parameters indicated in Table S1 (ESI $\dagger$ ). As shown further below, such optimized process also allowed a noteworthy reproducibility and stability without any encapsulation.

In Fig. 6, the cross-sectional SEM shows that the perovskite layer thickness is in the $560-600 \mathrm{~nm}$ range, exhibiting some defects in the layer bulk and at both interfaces with the ETL and HTL. This reveals that there is still room for improvement in order to further increase the performance, and reach that of
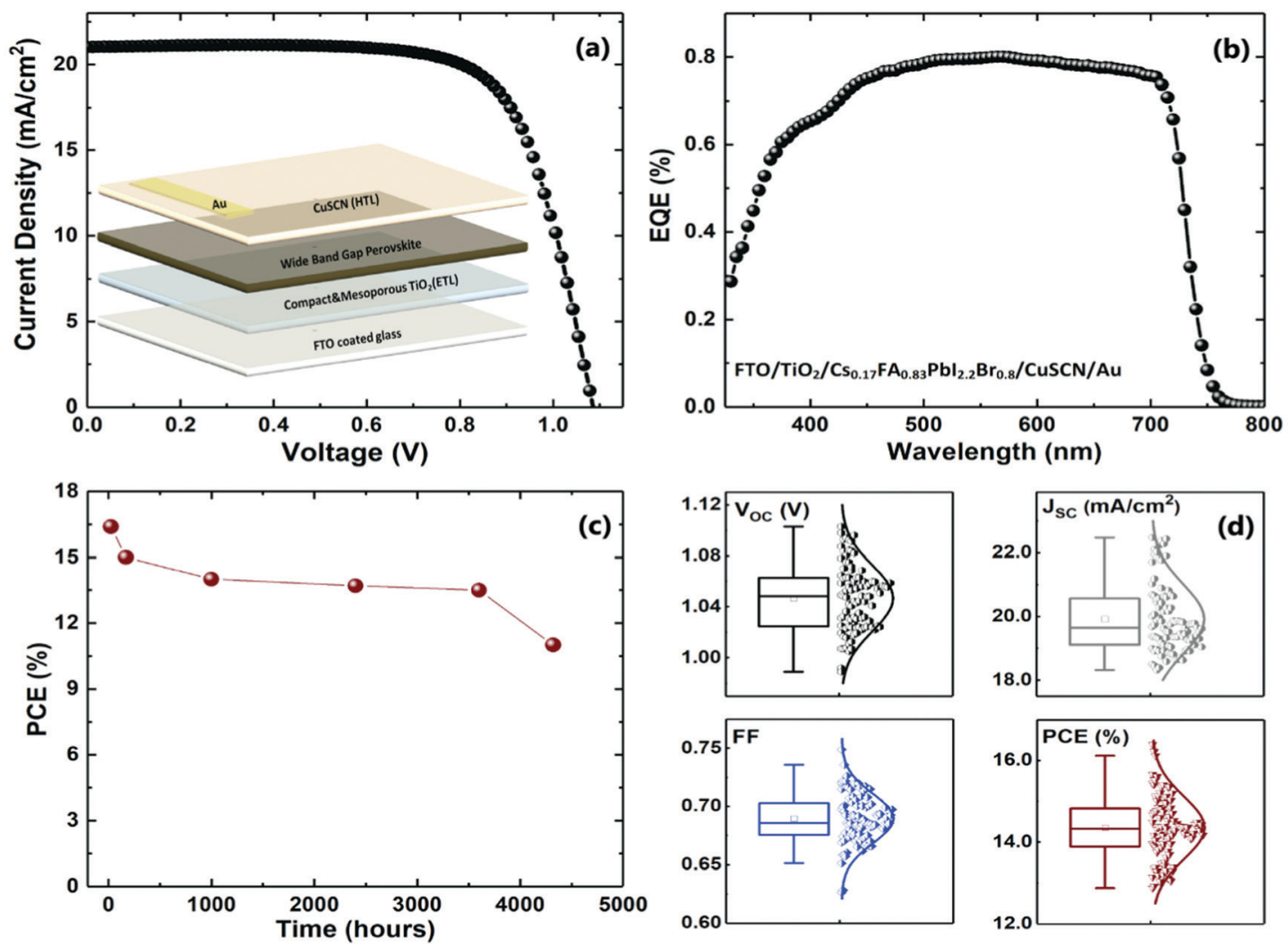

Fig. 7 J-V characteristic under AM 1.5 illumination (a), and EQE spectrum (b) of the best performing WBG (1.70 eV) PSC, which presents remarkable stability up to 4500 hours (c) even without any cell encapsulation. (d) Distribution and statistical analysis of the solar cell parameters of over 100 fabricated cells. 
state-of-the-art cells produced in a controlled glovebox environment. Moreover, the dark $I-V$ characteristic (Fig. S5, ESI $\dagger$ ) shows a high leakage current in reverse bias, causing a worse diode character, and thus reduced efficiency, compared to the record literature values with similar WBG-PSC structures. This also contributes to the commonly observed hysteresis effect of PSCs, shown in Fig. S6 of ESI, $\dagger$ attributed to the mobile ions/ion-vacancies in the perovskite material which cause a pronounced dependence of the cell $J V$ characteristic with the scan direction.

As referred before, Wang et al. ${ }^{31}$ described a "turbid point (TP)" observed during the perovskite layer deposition when the transparent perovskite film becomes turbid during the spin coating, and this point is dependent on the humidity levels of the ambient air. In our work, the most efficient PSC was achieved by preheating the substrates and applying antisolvent (chlorobenzene, CB) dripping 1-2 seconds before the turbid point, as well as by using warm antisolvent to help the solvent evaporation process and removal of oxygen and water. When the perovskite layers were deposited in $\leq 50 \% \mathrm{RH}$, compatible with Wang's observations, the turbid point appears sooner, and as a result, a thinner layer grows. We also applied the CB washing placing the pipette tip very close (less than $5 \mathrm{~mm}$ ) to the substrate, and noticed a significant enhancement on the perovskite layer formation. This impact can be attributed to speeding up the evaporation process, hence promoting better layer crystallization. Fig. S7 in ESI $\dagger$ shows the effects of key fabrication steps in the resulting $J V$ curves of the PSCs, whose optimization essentially allows minimizing the defect density in the perovskite layer and, thereby, improving the devices' performance. All in all, this study reinforces Wang's humidity insensitive antisolvent method, providing further understanding of the process of PSCs fabrication in humid ambient air.

To confirm the PSCs reproducibility, we fabricated more than 100 solar cells with WBG perovskite layers in the FTO/ compact-TiO $2 /$ meso-TiO $2 /(\mathrm{CsI})_{0.17}\left(\mathrm{FAI}_{0.83}\left(\mathrm{PbI}_{2}\right)_{0.6}\left(\mathrm{PbBr}_{2}\right)_{0.4} / \mathrm{CuSCN} /\right.$ $\mathrm{Au}$ configuration, and under $\sim 70 \% \mathrm{RH}$ ambient conditions. The $J-V$ characteristics and external quantum efficiency (EQE) measurements of the best performing cell are shown in Fig. 7a and $b$. The integrated current density values derived from the EQE spectra match that of the $J-V$ characteristics acquired with the solar simulator. Remarkably, without any encapsulation the best performing solar cell kept more than $80 \%$ of its initial efficiency for more than 3500 hours, and almost $70 \%$ after 4500 hours, which is shown in Fig. 7c.

In Fig. $7 \mathrm{~d}$, the solar cell parameters of the $E_{\mathrm{G}}=1.7 \mathrm{eV}$ PSCs are displayed over 100 fabricated devices. The main noteworthy aspect is that, although the humidity and temperature conditions in the laboratory are not controlled, the optimized process developed in this work allows highly reproducible cells with high efficiency values. The average of the $V_{\mathrm{oc}}, J_{\mathrm{sc}}, \mathrm{FF}$ and PCE values are $1.05 \mathrm{~V}, 19.9 \mathrm{~mA} \mathrm{~cm}{ }^{-2}, 0.70$ and $14.4 \%$, respectively. These results are among the best attained up to now in the PSCs' field, namely in comparison with the previous reported advances attained with un-encapsulated WBG PSCs fabricated in ambient humidity conditions. ${ }^{62,63}$

\section{Conclusions}

We present a low-cost glovebox-free procedure to contrive WBG PSCs, whose optical bandgap values were tuned between 1.66 to $1.74 \mathrm{eV}$ by changing the $\mathrm{Br}$ content in the perovskite structure. Here, the wrinkled morphology of the surface deteriorated the interface properties, and thus caused relatively lower efficiency for higher Br:I ratio. The perovskite layer with $1.70 \mathrm{eV}$ bandgap was selected for further optimization due to its potential application in tandem devices. A large set of mixed-cation mixed-halide WBG PSCs with $\mathrm{FTO} /$ compact-TiO ${ }_{2} /$ meso- $-\mathrm{TiO}_{2} /$ $(\mathrm{CsI})_{0.17}(\mathrm{FAI})_{0.83}\left(\mathrm{PbI}_{2}\right)_{0.6}\left(\mathrm{PbBr}_{2}\right)_{0.4} / \mathrm{CuSCN} / \mathrm{Au}$ configuration were fabricated, in which a record cell is reported with the best efficiency (16.4\%) attained thus far for ambient-processed WBG PSCs. In addition, this cell presents a remarkable stability, maintaining $80 \%$ of the initial efficiency for 3500 hours, and $70 \%$ up to 4500 hours. These outcomes reveal that it is possible to reproducibly fabricate high-performing and stable WBG PSCs without a controlled glovebox environment, and employing inexpensive charge transport materials such as the one used here (CuSCN) which is much cheaper than the conventional organic-based HTLs. This was attained via a humidity-insensitive antisolvent method, in which it was found crucial to preheat the substrate before the perovskite deposition, as well as to preheat the antisolvent and apply the antisolvent washing from a very close tip-sample distance, which enhances the evaporation and crystallization process of the perovskite film by reducing the moisture effects.

In addition to the set of morphological, structural and optoelectronic characterization techniques employed in this work, further insight into the role of the resulting bulk and interfaces' properties on the PSCs' transport mechanisms can be gained via electrochemical impedance/admittance analysis, which can also probe and provide a better understanding of the charge distribution and transfer within the PSC structure, including ion migration and, thus, hysteresis effects, as discussed in related works. ${ }^{38,64-68}$

Lastly, the main avenues that should be explored for further advances are the extended optimization of the absorber layer with wider (up to $\sim 2 \mathrm{eV}$ ) bandgap values, in view of application in tandem devices with silicon and low bandgap PSCs. Additionally, the implementation of photonic structures in the PSCs should be pursued, not only as a means to increase the photocurrent generation (and thereby the PCE) via light capturing and trapping, ${ }^{69}$ but also to improve the devices' stability against $\mathrm{UV}^{70,71}$ and water $^{72}$ penetration as demonstrated in recent contributions.

\section{Experimental methods}

\section{Materials}

All chemical reagents used in this study were purchased from commercial vendors. Formamidinium iodide (FAI) (Sigma Aldrich), lead iodide $\left(\mathrm{PbI}_{2}\right)$ (Sigma Aldrich), ceasium iodide (CsI) (Acros Organics), lead bromide ( $\mathrm{PbBr}_{2}$ ) (Sigma Aldrich), titanium IV-isopropoxide (TTIP) (Sigma Aldrich), titanium 
dioxide $\left(\mathrm{TiO}_{2}\right)$ paste (Sigma Aldrich), copper(I) thiocyanate (CuSCN) (Alfa Aeasar), diethyl sulfide (DES) (Sigma Aldrich), dimethylformamide (DMF) (Fisher Chemical), dimethyl sulfoxide (DMSO) (Panreac), chlorobenzene (CB) (Alfa Aeasar) were used without further purification.

\section{Substrate preparation and ETL layer deposition}

The wide-bandgap perovskite solar cells were fabricated with mesoscopic structure: Glass/FTO/TiO $2 / \mathrm{Cs}_{0.17} \mathrm{FA}_{0.83} \mathrm{PbI}_{3-x} \mathrm{Br}_{x} /$ $\mathrm{CuSCN} / \mathrm{Au}$. All the preparations and layer depositions were performed in ambient air with $\mathrm{RH}>70 \%$.

FTO-coated glasses (13 $\Omega \mathrm{sq}^{-1}, 82-84.5 \%$ of transmittance) were cut into $2 \times 2 \mathrm{~cm}$, then a $2 \mathrm{~mm}$ stripe of the FTO layer was etched with zinc powder and $\mathrm{HCl}$ solution, and afterwards cleaned by sonication with Hellmanex II, water, acetone, isopropanol alcohol and an additional step of $\mathrm{UV}-\mathrm{O}_{3}$ treatment to remove the organic compounds right before the deposition of the electron transport layer (ETL).

The first deposited layer of the solar cell is a very thin compact $\mathrm{TiO}_{2}$ film. The solution is prepared by a two-step method. Firstly, $180 \mu \mathrm{l}$ of TTIP was added to $1.25 \mathrm{ml}$ of absolute ethanol and placed onto a stirrer, and then $1.25 \mathrm{ml}$ of absolute ethanol with $18 \mu \mathrm{l}$ of HCL was added to the main solution. The compact $\mathrm{TiO}_{2}$ layers were deposited by spin coating for 35 seconds at $4000 \mathrm{rpm}$. After the spin coating, the layers were dried at $100{ }^{\circ} \mathrm{C}$ for 10 minutes, and then sintered in a furnace at $500{ }^{\circ} \mathrm{C}$ in ambient air. After the samples cool down to room temperature, another $\mathrm{UV}-\mathrm{O}_{3}$ treatment was applied for 15 minutes before the mesoporous $\mathrm{TiO}_{2}$ layer deposition. For this layer, $120 \mathrm{mg}$ of titania paste was dissolved in $1 \mathrm{ml}$ absolute ethanol and deposited by spin coating for 20 seconds at $4000 \mathrm{rpm}$, followed by a drying step at $120{ }^{\circ} \mathrm{C}$ for 10 minutes and sintering at $450{ }^{\circ} \mathrm{C}$ for 30 minutes in ambient air.

\section{Perovskite solutions and deposition}

The perovskite precursor solutions were prepared with the composition of $(\mathrm{CsI})_{0.17}(\mathrm{FAI})_{0.83}\left(\mathrm{PbI}_{2}\right)_{1-0.5 x}\left(\mathrm{PbBr}_{2}\right)_{0.5 x}$ using different bromide content by dissolving CsI (88.9 mg), FAI (285 mg) and $\mathrm{PbI}_{2}, \mathrm{PbBr}_{2}$ in $1 \mathrm{ml}$ mixture of DMF and DMSO (with a volume ratio of $9: 1$ ). For the bandgap variation, $x$ was chosen as $0.6,0.8$ and 1 during the precursor solution preparation. The precursor solutions were stirred at $70{ }^{\circ} \mathrm{C}$ until they reach a bright yellow colour. The solutions were filtered by a PTFE filter and the substrates coated with the ETL were heated up to $70{ }^{\circ} \mathrm{C}$ right before the deposition. The perovskite layer was deposited via a single-step deposition method with two different spin rates: $1000 \mathrm{rpm}$ for 10 seconds and then increases to followed by an increase to $5000 \mathrm{rpm}$ for a 20 seconds spin. Chlorobenzene was poured during the spinning at the higher spin rate to remove the solvents of the perovskite solution and improve crystallization. Soon after the deposition of the perovskite layer, the samples are annealed at $110{ }^{\circ} \mathrm{C}$ for 20 minutes on a hot plate covered by a Petri dish. As soon as the annealing process starts the layers turn to dark brown color from a light yellow one.

\section{Hole transport layer and metal contact deposition}

Following the perovskite layer deposition, CuSCN (copper(I) thiocyanate) was used as the hole transport material. Dissolving in diethyl sulfide, the solution was prepared as $0.3 \mathrm{M}$, filtered by a $0.45 \mu \mathrm{m}$ filter and deposited by spin coating for $20 \mathrm{~s}$ at $4000 \mathrm{rpm}$, followed by 5 minute annealing applied at $90{ }^{\circ} \mathrm{C}$ to evaporate the HTL solvent to avoid the deterioration of the perovskite layer. The gold back contacts were deposited by e-beam evaporation under high vacuum at a low deposition rate. The cells were produced with an active area of $0.10 \mathrm{~cm}^{2}$.

\section{Characterization techniques}

The optical transmission measurements were performed by UVVis-NIR spectrophotometry (PerkinElmer Lambda 950) in 300$800 \mathrm{~nm}$ wavelength range. Steady-state photoluminescence (PL) was measured by a PerkinElmer LS55, with an excitation at $400 \mathrm{~nm}$. Scanning Electron Microscopy (SEM) surface images were acquired by a TM3030 Plus Hitachi for lower and a Hitachi Regulus 8220 for higher magnification observations, and the corresponding grain size analysis was performed via ImageJ software. For the cross-sectional imaging, a Carl Zeiss AURIGA Cross Beam SEM work station was used. Surface topography Atomic Force Microscopy (AFM) images were obtained by an Asylum Research MFP-3D Standalone system using commercially available silicon AFM probes (Olympus AC160TS, $f_{0}=300 \mathrm{kHz}, k=26 \mathrm{~N} \mathrm{~m}^{-1}$ ). The X-ray diffraction (XRD) patterns were collected on a PANalytical XPert Pro X-ray powder diffractometer using Cu-Ka radiation $(\lambda=1.54050 \AA)$. The $J-V$ measurements were performed with Newport's Oriel ${ }^{\mathbb{R}}$ VeraSol LSH-7520 LED-based Solar Simulator (100 $\mathrm{mW} \mathrm{cm}^{-2}$ ) under AM 1.5 conditions, calibrated by a crystalline silicon reference cell (from VLSI Standards Inc.), in ambient conditions. A Keithley 2500 power source was used to apply voltages and collect current from the devices. The Quantum Efficiency measurements of the solar cells were carried out by Newport's QUANTX-300 system.

\section{Conflicts of interest}

There are no conflicts to declare.

\section{Acknowledgements}

This work was funded by FCT (Fundação para a Ciência e Tecnologia, I.P.) under the projects UIDB/50025/2020, SuperSolar (PTDC/NAN-OPT/28430/2017) and TACIT (PTDC/NANOPT/28837/2017). We also acknowledge the support of SYNERGY, H2020-WIDESPREAD-2020-5, CSA, proposal $\mathrm{n}^{\circ}$ 952169. U. D. Menda and G. Ribeiro acknowledge funding from FCT through the grants UIDP/50025/2020 and SFRH/BD/ 151095/2021, respectively.

\section{References}

1 A. Kojima, K. Teshima, Y. Shirai and T. Miyasaka, Organometal halide perovskites as visible-light sensitizers for 
photovoltaic cells, J. Am. Chem. Soc., 2009, 131, 6050-6051, DOI: $10.1021 /$ ja809598r.

2 NREL Best Research-Cell Efficiency Chart, (n.d.). https:// www.nrel.gov/pv/cell-efficiency.html (accessed February 1, 2021).

3 M. J. Brites, M. A. Barreiros, V. Corregidor, L. C. Alves, J. V. Pinto, M. J. Mendes, E. Fortunato, R. Martins and J. Mascarenhas, Ultrafast Low-Temperature Crystallization of Solar Cell Graded Formamidinium-Cesium Mixed-Cation Lead Mixed-Halide Perovskites Using a Reproducible Microwave-Based Process, ACS Appl. Energy Mater., 2019, 2, 1844-1853, DOI: 10.1021/acsaem.8b02005.

4 J. Troughton, D. Bryant, K. Wojciechowski, M. J. Carnie, H. Snaith, D. A. Worsley and T. M. Watson, Highly efficient, flexible, indium-free perovskite solar cells employing metallic substrates, J. Mater. Chem. A, 2015, 3, 9141-9145, DOI: 10.1039/c5ta01755f.

5 F. Yang, J. Liu, H. E. Lim, Y. Ishikura, K. Shinokita, Y. Miyauchi, A. Wakamiya, Y. Murata and K. Matsuda, High Bending Durability of Efficient Flexible Perovskite Solar Cells Using Metal Oxide Electron Transport Layer, J. Phys. Chem. C, 2018, 122, 17088-17095, DOI: 10.1021/ acs.jpcc.8b05008.

6 P. Docampo, J. M. Ball, M. Darwich, G. E. Eperon and H. J. Snaith, Efficient organometal trihalide perovskite planar-heterojunction solar cells on flexible polymer substrates, Nat. Commun., 2013, 4, 1-6, DOI: 10.1038/ ncomms3761.

7 F. Fu, T. P. Weiss, F. Fu, T. Feurer, T. P. Weiss, S. Pisoni, E. Avancini, C. Andres, S. Buecheler and A. N. Tiwari, Highefficiency inverted semi-transparent planar perovskite solar cells in substrate configuration, Nat. Energy, 2016, 1, 1690, DOI: 10.1038/nenergy.2016.190.

8 J. Werner, C. C. Boyd, T. Moot, E. J. Wolf, R. M. France, S. A. Johnson, M. F. A. M. van Hest, J. M. Luther, K. Zhu, J. J. Berry and M. D. McGehee, Learning from existing photovoltaic technologies to identify alternative perovskite module designs, Energy Environ. Sci., 2020, 13, 3393-3403, DOI: $10.1039 /$ d0ee01923b.

9 Y. Zhou, F. Wang, H. H. Fang, M. A. Loi, F. Y. Xie, N. Zhao and C. P. Wong, Distribution of bromine in mixed iodidebromide organolead perovskites and its impact on photovoltaic performance, J. Mater. Chem. A, 2016, 4, 16191-16197, DOI: 10.1039/c6ta07647e.

10 J. H. Heo, D. H. Song and S. H. Im, Planar CH3NH3PbBr3 hybrid solar cells with $10.4 \%$ power conversion efficiency, fabricated by controlled crystallization in the spin-coating process, Adv. Mater., 2014, 26, 8179-8183, DOI: 10.1002/ adma.201403140.

11 G. E. Eperon, T. Leijtens, K. A. Bush, R. Prasanna, T. Green, J. T. W. Wang, D. P. McMeekin, G. Volonakis, R. L. Milot, R. May, A. Palmstrom, D. J. Slotcavage, R. A. Belisle, J. B. Patel, E. S. Parrott, R. J. Sutton, W. Ma, F. Moghadam, B. Conings, A. Babayigit, H. G. Boyen, S. Bent, F. Giustino, L. M. Herz, M. B. Johnston, M. D. McGehee and H. J. Snaith, Perovskite-perovskite tandem photovoltaics with optimized band gaps, Science, 2016, 354, 861-865, DOI: 10.1126/science.aaf9717.

$12 \mathrm{~J}$. H. Heo and S. H. Im, $\mathrm{CH}_{3} \mathrm{NH}_{3} \mathrm{PbBr}_{3}-\mathrm{CH}_{3} \mathrm{NH}_{3} \mathrm{PbI}_{3}$ Perovskite-Perovskite Tandem Solar Cells with Exceeding $2.2 \mathrm{~V}$ Open Circuit Voltage, Adv. Mater., 2016, 5121-5125, DOI: 10.1002/adma.201501629.

13 D. Forgács, D. Pérez-Del-Rey, J. Ávila, C. Momblona, L. GilEscrig, B. Dänekamp, M. Sessolo and H. J. Bolink, Efficient wide band gap double cation-double halide perovskite solar cells, J. Mater. Chem. A, 2017, 5, 3203-3207, DOI: 10.1039/ c6ta10727c.

14 C. G. $\mathrm{Wu}$, C. H. Chiang and S. H. Chang, A perovskite cell with a record-high-Voc of $1.61 \mathrm{v}$ based on solvent annealed $\mathrm{CH}_{3} \mathrm{NH}_{3} \mathrm{PbBr}_{3} / \mathrm{ICBA}$ active layer, Nanoscale, 2016, 8, 4077-4085, DOI: 10.1039/c5nr07739g.

15 K. A. Bush, A. F. Palmstrom, Z. J. Yu, M. Boccard, R. Cheacharoen, J. P. Mailoa, D. P. McMeekin, R. L. Z. Hoye, C. D. Bailie, T. Leijtens, I. M. Peters, M. C. Minichetti, N. Rolston, R. Prasanna, S. Sofia, D. Harwood, W. Ma, F. Moghadam, H. J. Snaith, T. Buonassisi, Z. C. Holman, S. F. Bent and M. D. McGehee, 23.6\%-Efficient Monolithic Perovskite/Silicon Tandem Solar Cells With Improved Stability, Nat. Energy, 2017, 2, 17009, DOI: 10.1038/nenergy.2017.9.

16 M. Chapa, M. F. Alexandre, M. J. Mendes, H. Águas, E. Fortunato and R. Martins, All-Thin-Film Perovskite/C-Si Four-Terminal Tandems: Interlayer and Intermediate Contacts Optimization, ACS Appl. Energy Mater., 2019, 2, 3979-3985, DOI: 10.1021/acsaem.9b00354.

17 D. P. McMeekin, G. Sadoughi, W. Rehman, G. E. Eperon, M. Saliba, M. T. Hörantner, A. Haghighirad, N. Sakai, L. Korte, B. Rech, M. B. Johnston, L. M. Herz and H. J. Snaith, A mixed-cation lead mixed-halide perovskite absorber for tandem solar cells, Science, 2016, 351, 151-155, DOI: 10.1126/science.aad5845.

18 T. J. Jacobsson, A. Hultqvist, S. Svanström, L. Riekehr, U. B. Cappel, E. Unger, H. Rensmo, E. M. J. Johansson, M. Edoff and G. Boschloo, 2-Terminal CIGS-perovskite tandem cells: A layer by layer exploration, Sol. Energy, 2020, 207, 270-288, DOI: 10.1016/j.solener.2020.06.034.

19 H. Shen, T. Duong, J. Peng, D. Jacobs, N. Wu, J. Gong, Y. Wu, S. K. Karuturi, X. Fu, K. Weber, X. Xiao, T. P. White and K. Catchpole, Mechanically-stacked perovskite/CIGS tandem solar cells with efficiency of $23.9 \%$ and reduced oxygen sensitivity, Energy Environ. Sci., 2018, 11, 394-406, DOI: 10.1039/c7ee02627g.

20 Z. Song, C. L. McElvany, A. B. Phillips, I. Celik, P. W. Krantz, S. C. Watthage, G. K. Liyanage, D. Apul and M. J. Heben, A technoeconomic analysis of perovskite solar module manufacturing with low-cost materials and techniques, Energy Environ. Sci., 2017, 10, 1297-1305, DOI: 10.1039/c7ee00757d.

21 N. L. Chang, A. W. Yi Ho-Baillie, P. A. Basore, T. L. Young, R. Evans and R. J. Egan, A manufacturing cost estimation method with uncertainty analysis and its application to perovskite on glass photovoltaic modules, Prog. Photovoltaics Res. Appl., 2017, 25, 390-405, DOI: 10.1002/pip.2871. 
22 F. Sahli, J. Werner, B. A. Kamino, M. Bräuninger, R. Monnard, B. Paviet-Salomon, L. Barraud, L. Ding, J. J. Diaz Leon, D. Sacchetto, G. Cattaneo, M. Despeisse, M. Boccard, S. Nicolay, Q. Jeangros, B. Niesen and C. Ballif, Fully textured monolithic perovskite/silicon tandem solar cells with $25.2 \%$ power conversion efficiency, Nat. Mater., 2018, 17, 820-826, DOI: 10.1038/s41563-018-0115-4.

23 M. Saliba, J. P. Correa-Baena, C. M. Wolff, M. Stolterfoht, N. Phung, S. Albrecht, D. Neher and A. Abate, How to Make over 20\% Efficient Perovskite Solar Cells in Regular (n-i-p) and Inverted (p-i-n) Architectures, Chem. Mater., 2018, 30, 4193-4201, DOI: 10.1021/acs.chemmater.8b00136.

24 N. Yaghoobi Nia, M. Zendehdel, L. Cinà, F. Matteocci and A. Di Carlo, A crystal engineering approach for scalable perovskite solar cells and module fabrication: A full out of glove box procedure, J. Mater. Chem. A, 2018, 6, 659-671, DOI: $10.1039 / \mathrm{c} 7 \mathrm{ta0} 038 \mathrm{~g}$.

25 J. Yin, J. Cao, X. He, S. Yuan, S. Sun, J. Li, N. Zheng and L. Lin, Improved stability of perovskite solar cells in ambient air by controlling the mesoporous layer, J. Mater. Chem. A, 2015, 3, 16860-16866, DOI: 10.1039/c5ta02843d.

26 W. H. Chen, L. Qiu, Z. Zhuang, L. Song, P. Du, J. Xiong and F. Ko, Simple fabrication of perovskite solar cells with enhanced efficiency, stability, and flexibility under ambient air, J. Power Sources, 2019, 442, 1-8, DOI: 10.1016/ j.jpowsour.2019.227216.

27 F. Wang, Y. Zhongbiao, H. Sarvari, S. Park, K. Graham, Y. Zhao and Z. David Chen, Fabrication of Efficient $\mathrm{CH}_{3} \mathrm{NH}_{3} \mathrm{PbI}_{3}$ Solar Cells in Ambient Air, 2017 IEEE 44th Photovoltaic Specialist Conference (PVSC), 2018, 1044-1047, DOI: $10.1109 /$ pvsc.2017.8520927.

28 F. P. Gokdemir Choi, H. Moeini Alishah, S. Bozar, C. Doyranli, S. Koyuncu, N. San, C. Kahveci, M. Cantürk Rodop, M. B. Arvas, M. Gencten, Y. Sahin and S. Gunes, A novel interface layer for inverted perovskite solar cells fabricated in ambient air under high humidity conditions, Sol. Energy, 2020, 209, 400-407, DOI: 10.1016/j.solener.2020.08.013.

29 S. Pathak, A. Sepe, A. Sadhanala, F. Deschler, A. Haghighirad, N. Sakai, K. C. Goedel, S. D. Stranks, N. Noel, M. Price, S. Hüttner, N. A. Hawkins, R. H. Friend, U. Steiner and H. J. Snaith, Atmospheric influence upon crystallization and electronic disorder and its impact on the photophysical properties of organic-inorganic perovskite solar cells, ACS Nano, 2015, 9, 2311-2320, DOI: 10.1021/ nn506465n.

30 J. Troughton, K. Hooper and T. M. Watson, Humidity resistant fabrication of $\mathrm{CH} 3 \mathrm{NH} 3 \mathrm{PbI} 3$ perovskite solar cells and modules, Nano Energy, 2017, 39, 60-68, DOI: 10.1016/ j.nanoen.2017.06.039.

31 F. Wang, T. Zhang, Y. Wang, D. Liu, P. Zhang, H. Chen, L. Ji, L. Chen, Z. D. Chen, J. Wu, X. Liu, Y. Li and S. Li, Steering the crystallization of perovskites for high-performance solar cells in ambient air, J. Mater. Chem. A, 2019, 7, 12166-12175, DOI: $10.1039 /$ c9ta02566a.

32 K. Sveinbjörnsson, K. Aitola, J. Zhang, M. B. Johansson, X. Zhang, J. P. Correa-Baena, A. Hagfeldt, G. Boschloo and
E. M. J. Johansson, Ambient air-processed mixed-ion perovskites for high-efficiency solar cells, J. Mater. Chem. A, 2016, 4, 16536-16545, DOI: 10.1039/c6ta06912f.

33 Y. Cheng, X. Xu, Y. Xie, H. W. Li, J. Qing, C. Ma, C. S. Lee, F. So and S. W. Tsang, 18\% High-Efficiency Air-Processed Perovskite Solar Cells Made in a Humid Atmosphere of $70 \%$ RH, Sol. RRL, 2017, 1, 1-8, DOI: 10.1002/solr.201700097.

34 S. S. Shin, S. J. Lee and S. I. Seok, Exploring wide bandgap metal oxides for perovskite solar cells, APL Mater., 2019, 7, 022401, DOI: 10.1063/1.5055607.

35 N. Arora, M. I. Dar, A. Hinderhofer, N. Pellet, F. Schreiber, S. M. Zakeeruddin and M. Grätzel, Perovskite solar cells with CuSCN hole extraction layers yield stabilized efficiencies greater than 20\%, Science, 2017, 358, 768-771, DOI: 10.1126/science.aam5655.

36 C. Yang, M. Yu, D. Chen, Y. Zhou, W. Wang, Y. Li, T. C. Lee and D. Yun, An annealing-free aqueous-processed anatase TiO2 compact layer for efficient planar heterojunction perovskite solar cells, Chem. Commun., 2017, 53, 10882-10885, DOI: $10.1039 / \mathrm{c} 7 \mathrm{cc} 01104 \mathrm{k}$.

37 M. Saliba, S. Orlandi, T. Matsui, S. Aghazada, M. Cavazzini, J. P. Correa-Baena, P. Gao, R. Scopelliti, E. Mosconi, K. H. Dahmen, F. De Angelis, A. Abate, A. Hagfeldt, G. Pozzi, M. Graetzel and M. K. Nazeeruddin, A molecularly engineered hole-transporting material for efficient perovskite solar cells, Nat. Energy, 2016, 1, 1-7, DOI: 10.1038/ nenergy.2015.17.

38 H. H. Wang, Q. Chen, H. Zhou, L. Song, Z. St Louis, N. De Marco, Y. Fang, P. Sun, T. Bin Song, H. Chen and Y. Yang, Improving the $\mathrm{TiO} 2$ electron transport layer in perovskite solar cells using acetylacetonate-based additives, J. Mater. Chem. A, 2015, 3, 9108-9115, DOI: 10.1039/c4ta06394e.

39 B. Wang, M. Zhang, X. Cui, Z. Wang, M. Rager, Y. Yang, Z. Zou, Z. L. Wang and Z. Lin, Unconventional Route to Oxygen-Vacancy-Enabled Highly Efficient Electron Extraction and Transport in Perovskite Solar Cells, Angew. Chem., Int. Ed., 2020, 59, 1611-1618, DOI: 10.1002/anie.201910471.

40 H. Li, Y. Xue, B. Zheng, J. Tian, H. Wang, C. Gao and X. Liu, Interface modification with PCBM intermediate layers for planar formamidinium perovskite solar cells, RSC Adv., 2017, 7, 30422-30427, DOI: 10.1039/c7ra04311b.

41 C. Lu, I. T. Choi, J. Kim and H. K. Kim, Simple synthesis and molecular engineering of low-cost and star-shaped carbazole-based hole transporting materials for highly efficient perovskite solar cells, J. Mater. Chem. A, 2017, 5, 20263-20276, DOI: 10.1039/c7ta04762b.

42 T. P. I. Saragi, T. Spehr, A. Siebert, T. Fuhrmann-Lieker and J. Salbeck, Spiro compounds for organic optoelectronics, Chem. Rev., 2007, 107, 1011-1065, DOI: 10.1021/cr0501341.

43 A. T. Murray, J. M. Frost, C. H. Hendon, C. D. Molloy, D. R. Carbery and A. Walsh, Modular design of SPIROOMeTAD analogues as hole transport materials in solar cells, Chem. Commun., 2015, 51, 8935-8938, DOI: 10.1039/ c5cc02129d.

44 I. S. Yang, S. Lee, J. Choi, M. T. Jung, J. Kim and W. I. Lee, Enhancement of open circuit voltage for CuSCN-based 
perovskite solar cells by controlling the perovskite/CuSCN interface with functional molecules, J. Mater. Chem. A, 2019, 7, 6028-6037, DOI: 10.1039/c8ta12217b.

45 F. Ma, Y. Zhao, J. Li, X. Zhang, H. Gu and J. You, Nickel oxide for inverted structure perovskite solar cells, J. Energy Chem., 2020, 52, 393-411, DOI: 10.1016/j.jechem.2020.04.027.

46 T. Abzieher, S. Moghadamzadeh, F. Schackmar, H. Eggers, F. Sutterlüti, A. Farooq, D. Kojda, K. Habicht, R. Schmager, A. Mertens, R. Azmi, L. Klohr, J. A. Schwenzer, M. Hetterich, U. Lemmer, B. S. Richards, M. Powalla and U. W. Paetzold, Electron-Beam-Evaporated Nickel Oxide Hole Transport Layers for Perovskite-Based Photovoltaics, Adv. Energy Mater., 2019, 9, 1-13, DOI: 10.1002/aenm.201802995.

47 P. Yang, J. Wang, X. Zhao, J. Wang, Z. Hu, Q. Huang and L. Yang, Magnetron-sputtered nickel oxide films as hole transport layer for planar heterojunction perovskite solar cells, Appl. Phys. A: Mater. Sci. Process., 2019, 125, 1-6, DOI: 10.1007/s00339-019-2769-4.

48 R. Segovia, G. Qu, M. Peng, X. Sun, H. Shi and B. Gao, Evolution of Photoluminescence, Raman, and Structure of CH3NH3PbI3 Perovskite Microwires Under Humidity Exposure, Nanoscale Res. Lett., 2018, 13, 0-7, DOI: 10.1186/ s11671-018-2470-0.

49 A. Tejada, S. Braunger, L. Korte, S. Albrecht, B. Rech and J. A. Guerra, Optical characterization and bandgap engineering of flat and wrinkle-textured $\mathrm{FA}_{0.83} \mathrm{Cs}_{0.17} \mathrm{~Pb}\left(\mathrm{I}_{1-x} \mathrm{Br}_{x}\right)_{3}$ perovskite thin films, J. Appl. Phys., 2018, 123, 0-7, DOI: 10.1063/1.5025728.

50 M. Saliba, T. Matsui, J. Y. Seo, K. Domanski, J. P. CorreaBaena, M. K. Nazeeruddin, S. M. Zakeeruddin, W. Tress, A. Abate, A. Hagfeldt and M. Grätzel, Cesium-containing triple cation perovskite solar cells: Improved stability, reproducibility and high efficiency, Energy Environ. Sci., 2016, 9, 1989-1997, DOI: 10.1039/c5ee03874j.

51 R. Garc, D. Ferdani, S. Pering and P. J. Baker, Influence of bromide content on iodide migration in inverted $\operatorname{MAPb}\left(\mathrm{I}_{1-x} \mathrm{Br}_{x}\right)_{3}$ perovskite solar cells, J. Mater. Chem. A, 2019, 22604-22614, DOI: 10.1039/c9ta08848b.

52 W. Rehman, D. P. McMeekin, J. B. Patel, R. L. Milot, M. B. Johnston, H. J. Snaith and L. M. Herz, Photovoltaic mixed-cation lead mixed-halide perovskites: Links between crystallinity, photo-stability and electronic properties, Energy Environ. Sci., 2017, 10, 361-369, DOI: 10.1039/c6ee03014a.

53 K. A. Bush, N. Rolston, A. Gold-Parker, S. Manzoor, J. Hausele, Z. J. Yu, J. A. Raiford, R. Cheacharoen, Z. C. Holman, M. F. Toney, R. H. Dauskardt and M. D. McGehee, Controlling Thin-Film Stress and Wrinkling during Perovskite Film Formation, ACS Energy Lett., 2018, 3, 1225-1232, DOI: 10.1021/acsenergylett.8b00544.

54 S. Braunger, L. E. Mundt, C. M. Wolff, M. Mews, C. Rehermann, M. Jošt, A. Tejada, D. Eisenhauer, C. Becker, J. A. Guerra, E. Unger, L. Korte, D. Neher, M. C. Schubert, B. Rech and S. Albrecht, $\mathrm{Cs}_{x} \mathrm{FA}_{1-x} \mathrm{~Pb}\left(\mathrm{I}_{1-y} \mathrm{Br}_{y}\right)_{3}$ Perovskite Compositions: The Appearance of Wrinkled Morphology and its Impact on Solar Cell Performance, J. Phys. Chem. C, 2018, 122, 17123-17135, DOI: 10.1021/acs.jpcc.8b06459.
55 B. Chen, S. W. Baek, Y. Hou, E. Aydin, M. De Bastiani, B. Scheffel, A. Proppe, Z. Huang, M. Wei, Y. K. Wang, E. H. Jung, T. G. Allen, E. Van Kerschaver, F. P. García de Arquer, M. I. Saidaminov, S. Hoogland, S. De Wolf and E. H. Sargent, Enhanced optical path and electron diffusion length enable high-efficiency perovskite tandems, Nat. Commun., 2020, 11, 1257, DOI: 10.1038/s41467-020-15077-3.

56 R. E. Beal, N. Z. Hagström, J. Barrier, A. Gold-Parker, R. Prasanna, K. A. Bush, D. Passarello, L. T. Schelhas, K. Brüning, C. J. Tassone, H. G. Steinrück, M. D. McGehee, M. F. Toney and A. F. Nogueira, Structural Origins of Light-Induced Phase Segregation in OrganicInorganic Halide Perovskite Photovoltaic Materials, Matter, 2020, 2, 207-219, DOI: 10.1016/j.matt.2019.11.001.

57 J. Ye, G. Liu, L. Jiang, H. Zheng, L. Zhu, X. Zhang, H. Wang, X. Pan and S. Dai, Crack-free perovskite layers for high performance and reproducible devices via improved control of ambient conditions during fabrication, Appl. Surf. Sci., 2017, 407, 427-433, DOI: 10.1016/j.apsusc.2017.02.135.

58 D. B. Khadka, Y. Shirai, M. Yanagida, T. Masuda and K. Miyano, Enhancement in efficiency and optoelectronic quality of perovskite thin films annealed in MACl vapor, Sustain, Energy Fuels, 2017, 1, 755-766, DOI: 10.1039/c7se00033b.

59 S. Mahesh, J. M. Ball, R. D. J. Oliver, D. P. McMeekin, P. K. Nayak, M. B. Johnston and H. J. Snaith, Revealing the origin of voltage loss in mixed-halide perovskite solar cells, Energy Environ. Sci., 2020, 13, 258-267, DOI: 10.1039/ c9ee02162k.

60 M. I. Hossain, W. Qarony, S. Ma, L. Zeng, D. Knipp and Y. H. Tsang, Perovskite/Silicon Tandem Solar Cells: From Detailed Balance Limit Calculations to Photon Management, Nano-Micro Lett., 2019, 11, 58, DOI: 10.1007/s40820019-0287-8.

61 K. T. Cho, S. Paek, G. Grancini, C. Roldán-Carmona, P. Gao, Y. Lee and M. K. Nazeeruddin, Highly efficient perovskite solar cells with a compositionally engineered perovskite/ hole transporting material interface, Energy Environ. Sci., 2017, 10, 621-627, DOI: 10.1039/c6ee03182j.

62 I. M. Asuo, D. Gedamu, N. Y. Doumon, I. Ka, A. Pignolet, S. G. Cloutier and R. Nechache, Ambient conditionprocessing strategy for improved air-stability and efficiency in mixed-cation perovskite solar cells, Mater. Adv., 2020, 1, 1866-1876, DOI: 10.1039/d0ma00528b.

63 P. Luo, W. Xia, S. Zhou, L. Sun, J. Cheng, C. Xu and Y. Lu, Solvent Engineering for Ambient-Air-Processed, PhaseStable CsPbI3 in Perovskite Solar Cells, J. Phys. Chem. Lett., 2016, 7, 3603-3608, DOI: 10.1021/acs.jpclett.6b01576.

64 L. Contreras-Bernal, S. Ramos-Terrón, A. Riquelme, P. P. Boix, J. Idígoras, I. Mora-Seró and J. A. Anta, Impedance analysis of perovskite solar cells: A case study, J. Mater. Chem. A, 2019, 7, 12191-12200, DOI: 10.1039/c9ta02808k.

65 B. Hailegnaw, N. S. Sariciftci and M. C. Scharber, Impedance Spectroscopy of Perovskite Solar Cells: Studying the Dynamics of Charge Carriers Before and After Continuous Operation, Phys. Status Solidi A, 2020, 217, 1-8, DOI: 10.1002/pssa.202000291. 
66 H. Wang, A. Guerrero, A. Bou, A. M. Al-Mayouf and J. Bisquert, Kinetic and material properties of interfaces governing slow response and long timescale phenomena in perovskite solar cells, Energy Environ. Sci., 2019, 12, 2054-2079, DOI: 10.1039/c9ee00802k.

67 R. A. Awni, Z. Song, C. Chen, C. Li, C. Wang, M. A. Razooqi, L. Chen, X. Wang, R. J. Ellingson, J. V. Li and Y. Yan, Influence of Charge Transport Layers on Capacitance Measured in Halide Perovskite Solar Cells, Joule, 2020, 4, 644-657, DOI: 10.1016/j.joule.2020.01.012.

68 A. Fakharuddin, L. Schmidt-Mende, G. Garcia-Belmonte, R. Jose and I. Mora-Sero, Interfaces in Perovskite Solar Cells, Adv. Energy Mater., 2017, 7, 1700623, DOI: 10.1002/ aenm.201700623.

69 S. Haque, M. Alexandre, M. J. Mendes, H. Águas, E. Fortunato and R. Martins, Design of wave-optical structured substrates for ultra-thin perovskite solar cells, Appl.
Mater. Today, 2020, 20, 100720, DOI: 10.1016/ j.apmt.2020.100720.

70 M. Alexandre, M. Chapa, S. Haque, M. J. Mendes, H. Águas, E. Fortunato and R. Martins, Optimum Luminescent DownShifting Properties for High Efficiency and Stable Perovskite Solar Cells, ACS Appl. Energy Mater., 2019, 2, 2930-2938, DOI: $10.1021 /$ acsaem.9b00271.

71 O. Sanchez-Sobrado, M. J. Mendes, T. Mateus, J. Costa, D. Nunes, H. Aguas, E. Fortunato and R. Martins, Photonic-structured TCO front contacts yielding optical and electrically enhanced thin-film solar cells, Sol. Energy, 2020, 196, 92-98, DOI: 10.1016/j.solener.2019.11.051.

72 P. Centeno, M. F. Alexandre, M. Chapa, J. V. Pinto, J. Deuermeier, T. Mateus, E. Fortunato, R. Martins, H. Águas and M. J. Mendes, Self-Cleaned PhotonicEnhanced Solar Cells with Nanostructured Parylene-C, Adv. Mater. Interfaces, 2020, 7, 1-9, DOI: 10.1002/admi.202000264. 